\section{Wstęp: Perspektywy biopolityki}

Gdy w latach siedemdziesiątych dwudziestego wieku Michel Foucault wprowadził do swojego dyskursu termin „biopolityka”, przeszłość i przyszłość tego pojęcia były jeszcze niejasne. $U$ francuskiego filozofa funkcjonowało ono jako użyteczne narzędzie, za pomocą którego możliwa była genealogiczna rekonstrukcja transformacji pola społecznego i zawiązywania się nowych relacji władzy, sukcesywnie obejmujących całe życie jednostki, wraz z jej wymiarem cielesnym, seksualnym czy biologicznym. Foucault nie podjął się jednak nigdy prześledzenia genealogii samego pojęcia, którego losy pokrywają się w dużej mierze z burzliwą historią dwudziestego wieku.

Do interesującego nas terminu odwoływali się nazistowscy projektanci czystości rasy, ekolodzy czy technocentryczni teoretycy polityki. Za pierwszego teoretyka biopolityki należałoby uznać jednak Karola Marksa. To on zdiagnozował i systematycznie wyłożył logikę mechanizmu, który rewolucjonizując środki produkcji i ich organizację, podporządkowuje z wolna całe społeczeństwo jednej zasadzie - zasadzie kapitału. Foucault w Historii seksualności przyznaje otwarcie, że biowładza była jedną z niezbędnych części składowych rozwoju kapitalizmu. Ceną, jaką ten system gospodarczy musiał zapłacić za swoje przetrwanie, było włączenie ciał w kapitalistyczny aparat produkcji oraz sprzęgnięcie rozwoju populacji z procesami ekonomicznymi. Pierwszy z członów tego procesu Marks uchwycił precyzyjnie w tzw. Fragmencie o maszynach. Drugi został opracowany przez Foucaulta podczas wykładów w Collège de France. Warto jednak dodać, że w czasach, gdy śledził on związki między biopolityką i liberalizmem, procesy ekonomiczne oraz innowacje technologiczne, które określają naszą współczesność, nie znajdowały się jeszcze w swoim szczytowym stadium.

We wspomnianym powyżej Fragmencie o maszynach Marks przeczuwał już moment, w którym na skutek rozwoju kapitału trwałego wiedza, ale również całość realnego procesu życia, staną się podstawowymi i niezbędnymi siłami wytwórczymi. Hegemoniczne sektory współczesnej gospodarki (z uwagi na zarysowywaną tendencję, nie wskaźniki ilościowe) oparte są w prze- ważającym stopniu na usługach, przetwarzaniu wiedzy, kreatywności podmiotów i ich wzajemnej komunikacji. Ten stan kojarzyć się może z młodomarksowską wizją komunizmu, w której po pozytywnym zniesieniu własności prywatnej następuje stan "produkcji człowieka przez człowieka”. W jej ramach, za sprawą pewnego rodzaju działalności wytwórczej (np. w sektorze usług, komunikacji itp.), przekształceniu ulega podział na przedmiot i podmiot produkcji - człowiek/podmiot wytwarza i człowiek/podmiot jest wytwarzany. Autorzy tacy, jak Michael Hardt i Antonio Negri nawiązują do tej wizji, rozpoznając w owej gospodarczej transformacji miejsce wyłaniania się nowych postaci antagonizmów społecznych. Proponują odróżnienie oddolnej, produktywnej biopolityki od opresyjnej biowładzy. Różnica ta miałaby wskazywać, z jednej strony, na rosnącą autonomię żywej pracy, z drugiej, na nasilenie się procesów podporządkowywania tej autonomii zewnętrznym mechanizmom kapitalistycznej kontroli.

Jak przekonują autorzy prezentowanego numeru (tacy jak Hardt i Negri, Marcello Tarì czy Bülent Diken), dwoistość biopolityki, o której mowa powyżej, znajduje swoją najlepszą materializację na gruncie targanej wewnętrznymi sprzecznościami metropolii. Choć podjęcie tematyki miejskiej to w tym wypadku raczej ponowna próba wypełnienia białej plamy na mapie filozofii marksowskiej (z godnym uwagi wyjątkiem w postaci Potożenia klasy robotniczej w Anglii Engelsa) aniżeli spadek po „miejskich” pracach samego autora Kapitatu, nie sposób forsować tezy o biopolityzacji metropolii w oderwaniu od klasycznych analiz Marksa (poświęconych zagadnieniu renty czy nowoczesnemu grodzeniu terenów komunalnych). Współczesna metropolia to odpowiednik nowoczesnej fabryki, zasięg jej stale przesuwających się granic pokrywa się z konturami przestrzeni ludzkiej (i nie-ludzkiej) produktywności. Stanowi zarazem ogromny obóz pracy (jak przekonywałby kładący nacisk na opresyjność odgórnej biopolityki Giorgio Agamben), obszar nieskrępowanego wyzysku i prywatyzacji dobra wspólnego, jak i przestrzeń demokratycznego oporu wymierzonego w metropolitalną metonimię kapitału znajdującego się w fazie imperialnej (zgodnie z afirmatywną wizją biopolityki oddolnej prezentowanej w Multitude czy Commonwealth 
Hardta i Negriego). Poza wszystkim, miasto biopolityczne to pełen optymizmu dowód na pierwotność tego ostatniego (zgodnie z Foucaultowsko-Deleuzjańską aksjomatyką pierwszeństwa oporu, ale i z uporem rewitalizowaną zasadą średniowiecznych miast niemieckich - „Stadtluft macht frei”) i warunek konieczny ostatecznego zwycięstwa „żywej polityki miasta” - za sprawą wyłączania urządzeń władzy, demokratycznej organizacji „firmowego” znaku metropolii, spontanicznych, nieoczekiwanych spotkań, i ich przekraczania w ramach ponadlokalnych walk.

Życia i żywej pracy nie można już jednak rozumieć jako żywiołu, elementu niezależnego od technologii czy od innych postaci biologicznego istnienia. Począwszy od lat siedemdziesiątych i osiemdziesiątych biotechnologiczne innowacje zdecydowanie zaburzyły nasze postrzeganie świata i nas samych. Możliwości ingerencji w strukturę żywych organizmów, poznanie składu genomu ludzkiego oraz wykorzystanie na przemysłową skalę zmodyfikowanych genetycznie postaci życia to nowe wyzwania biopolityczne (o czym w niniejszym numerze pisze Nikolas Rose). Biopolityka nie może dotyczyć już tylko ludzkiego życia - pole jej analiz zaczyna obejmować życie jako takie: pracujące, produkujące wartość, współokreślane w każdym swoim aspekcie przez technologię.

Dlatego też biopolityka musi podjąć dziś zagadnienia, które kształtowały przez wieki dyskurs teorii polityki (być może biopolityka jest dzisiaj nową nazwą filozofii politycznej jako takiej?). Jednym z nich jest pytanie o postać kolektywnego życia, o nową wizję wspólnoty. Forma, jaką powinna przybrać wspólnotowa egzystencja, zależy od zmieniających się pojedynczych form życia i tego, w jaki sposób artykułują one oraz komunikują swoje potrzeby i pragnienia. Globalne sieci przepływu towarów i informacji wytworzyły środowisko, które umożliwia rozwinięcie się nowych postaci społecznego współ-życia, opartego na zmieniającej się logice dostępu do wiedzy i innych dóbr niematerialnych.

Biopolityka jest pojęciem, które zmienia się tak samo dynamicznie, jak jego przedmiot, który ostatecznie zrównany być może z całym polem społecznym. Nie przesądza ona jednak z góry, czym są elementy składające się na kolektywną egzystencję, ani w jaki sposób zawiązują się między nimi relacje. Wszelkie analizy korzystające z tego pojęcia stanowią jednocześnie moment teoretycznego oporu - określają bowiem kontury tego, czym jest życie społeczne, polityczne i gospodarcze. Odwołują się do historii, ustaleń nauk przyrodniczych, teorii ekonomicznych, filozoficznych analiz pojęciowych itd. - ponieważ wszystkie te elementy współkonstytuują formę naszego życia-razem.

Drugi numer naszego pisma powstał jako rezultat kolektywnego wysiłku w ramach seminarium Biopolityka - wprowadzenie systematyczne, przeprowadzonego w 2010 roku w Pracowni Pytań Granicznych UAM, oraz konferencji Perspektywy biopolityki, która odbyła się w dniach 25-27 marca 2010 roku w Poznaniu. Stanowi przykład praktyki teoretycznego oporu, którego celem jest radykalne zapytywanie o wizję współczesnego życia wspólnotowego. W epoce, w której społeczeństwo, a w zasadzie życie jako całość, podporządkowane jest mechanizmom produkcji, wyzysku i kontroli, w wieku gwałtownie postępującej denaturalizacji potrzebna jest polityka, która będzie polityką życia samego. Jesteśmy przekonane i przekonani, że przedkładane Wam teksty stanowić mogą skromny przyczynek do owego przedsięwzięcia.

Praktyka Teoretyczna 